\title{
DNA Fingerprinting and the Right to Inviolability of the Body and Bodily Integrity in the Netherlands: Convincing Evidence and Proliferating Body Parts
}

\section{VICTOR TOOM}

\begin{abstract}
The paper uses insights from the so-called rape in disguise case study to describe forensic DNA practices in the Netherlands in late 1980s. It describes how "reliabilities" of forensic DNA practices were achieved. One such reliability convincing evidence - proliferates body parts through time and space. Then, attention shifts to the individual who was suspected of having committed the rape. He was asked to deliver tissue for DNA typing, but refused to do so. Hence DNA typing could not be used to connect the suspect to a cervical smear collected from the body of the victim. His refusal and the legal impossibility to use force to obtain his biological material led first to questions in the Dutch parliament and then to the Dutch forensic DNA law. Other legal measures enacted after this are also described. I argue that, by means of the various Dutch forensic DNA laws and new forensic genetic techniques, the application of forensic DNA practices have shifted from identification and evidence to a tool for criminal investigation and prevention of future crimes. In the final part of the paper, the right to inviolability of the body and its synonym bodily integrity are emphasised. I argue that despite the various forensic DNA laws, bodily integrity of obtained tissue for DNA typing is still at stake as the result of convincing evidence.
\end{abstract}

\section{Introduction}

Since the invention of the so-called DNA fingerprint by geneticist Alec Jeffreys and his colleagues in the mid $1980 \mathrm{~s},{ }^{1}$ it has been possible to individualise persons genetically, much as dactyloscopy (fingerprinting) is used to individualise people physically. It has proven to be a very important forensic technique; DNA typing is considered the new gold standard of forensic evidence in the court of law. When DNA fingerprinting was introduced to the Dutch judiciary, it turned out that the law was not compatible with this new technique, as a suspect could refuse to cooperate with DNA typing. Hence, DNA fingerprinting could only be used with the consent of a suspect; if a suspect refused to deliver tissue, DNA typing could not be used to connect the suspect to, for instance, a cervical smear collected from the body of a victim of rape. Such a situation happened in the rape in disguise case that shall be described in this paper. ${ }^{2}$ Information from the criminal file of that case is used here to describe the organisation of Dutch forensic DNA practices in the late 1980s. ${ }^{3}$ More specifically, three forms of "reliability" of forensic DNA practices - reproducibility, legal evidence, convincing evidence - are described. I argue that body parts of individuals whose tissue will be DNA typed proliferate through time and space as the result of convincing evidence. After introducing the case and describing the achievement of reliable forensic DNA, I explain how the case could not be solved as the suspect refused to deliver blood or saliva for DNA typing. His refusal and the legal impossibility to use force to obtain his biological material led first to questions 
in Dutch Parliament and then to the Dutch forensic DNA law. Other legal measures enacted after this will also be described. I argue that, by means of the various Dutch forensic DNA laws and new forensic genetic techniques, the application of forensic DNA practices shifted from identification and evidence to a tool for criminal investigation and prevention of future crimes. These shifts in applicability have repercussions for the legal principles that organise relations between the State and civilians. One such legal measure is the right to inviolability of the body, which is a synonym for bodily integrity. This legal concept is understood currently as the right not to be touched by the authorities. The argument presented in this paper is that bodily integrity of body parts proliferated through time and space is jeopardised.

\section{Rape in disguise}

In one of the southern Dutch provinces a young woman was raped in the late 1980s. The perpetrator was disguised through wearing a costume, hence the name of the case. ${ }^{4}$ The rape was investigated by the police. Various forensic techniques were applied, among them the novel DNA fingerprint technique. After the victim was found she was brought to the hospital where she was physically examined by a medical doctor. A cervical smear was taken and other biological material like pubic hairs were collected. Considering the nature of the crime, it was expected that the collected tissue and traces contained material that belonged to the alleged perpetrator. Reference material from the victim was also collected, so as to be able to discriminate between material that belongs to the victim and alleged perpetrator. As the rape appeared to have a similar modus operandi as another rape committed in the same region a year earlier, forensic analysts produced, at the request of the public prosecutor, DNA fingerprints from the cervical smears collected from both victims. By comparing the DNA fingerprints of blood collected from both victims with the DNA fingerprints of the cervical smears the forensic analysts were able to reconstruct two DNA fingerprints from each cervical smear. In both cases, the DNA fragments found that did not belong to the two victims matched, making it very probable that the DNA fingerprints originated from the same individual. Such a match is expressed in a statistical number called the likelihood ratio, which indicates the odds that a matching DNA fingerprint originates from two individuals. In this case the found likelihood ratio was $1: 8,000$, meaning that one in 8,000 individuals will statistically have the same DNA fingerprint. ${ }^{5}$

A statistical number like 1:8,000 is hard to neglect for police officers, judges, and public prosecutors; a high likelihood ratio translates a match into a scientific and hence "reliable" fact. But reliability of evidence is about more than statistical outcomes. In this section, I discuss various notions of "reliability" relating to forensic DNA practices. Reliability is in quotation marks not because the reliability of forensic DNA practices will be questioned, but because this reliability is achieved in different ways. ${ }^{6}$ In this paper, DNA is considered as evidence resulting from (at least) three areas: technoscience, law, and judiciary. In each area, practitioners work according to their own rules, logic and merits, which imply different kinds of materials, norms, standards, expertise, knowledge, and settings, and hence produce different kinds of reliability. 
Within a forensic laboratory, reliability is subject to a regime of reproducibility. To be able to reproduce results it is of the utmost importance that an analyst's work is standardised, that proper protocols and research strategies are deployed, and that dates, times, lot numbers, machines, techniques, and expiration dates of used chemicals are conscientiously written into a laboratory diary. Being subjected to a regime of reproducibility also means that analysts work in sterile conditions to prevent contamination of crime related samples. Hence, achieving reliability is also a result of cleaning, decontamination, and wearing rubber gloves. Techno-scientific results have to be communicated to jurists, i.e. lawyers, judges, or public prosecutors. By means of this communication, the results travel from a scientific practice to juridical practice. Jurists have a different educational background; they are lay persons when it concerns understanding and interpreting DNA profiles. Translation and application of techno-scientific data into the judiciary must be trustworthy. Trustworthy translation and application is achieved by various legal arrangements in the Netherlands. For example, the Dutch forensic institute (Nederlands Forensisch Instituut, NFI) resides directly under the Minister of Justice, and the tasks of the NFI are circumscribed in Dutch law. Forensic evidence gains legal status only if it is produced in forensic laboratories with specific international accreditation; only two Dutch forensic DNA laboratories have such accreditation. ${ }^{7}$ Forensic experts are responsible for reporting the results to the judiciary; a legal precondition to become a forensic expert is that they are sworn-in. Transforming techno-scientific results into trustworthy evidence is achieved through legal arrangements and thus creates legal evidence as a second form of reliable evidence. Besides being legal, evidence needs to be convincing, too. It is up to the judge to become convinced of the relevance of evidence in the case at hand; a demonstrably unbroken chain of evidence enables the judge to make such a decision. The chain of evidence is the result of describing, registering, and administrating all steps from collecting tissue until the presentation of it as evidence in the court of law, giving the judge the opportunity to trace back all phases of production of evidence. Therefore, the chain of evidence has to be transparent. ${ }^{8}$ If a chain of evidence is not demonstrably unbroken, a judge or a lawyer will doubt the origins of either the tissue found at the crime scene or a sample taken from a suspect. Hence, it is not that evidence is convincing; it is that it has to be made convincing. ${ }^{9}$ In a simplified, linear mode (fig. 1), two chains of evidence (the "suspect chain" and the "crime scene chain") can be bound together by a match.

Figure 1. Chain of evidence

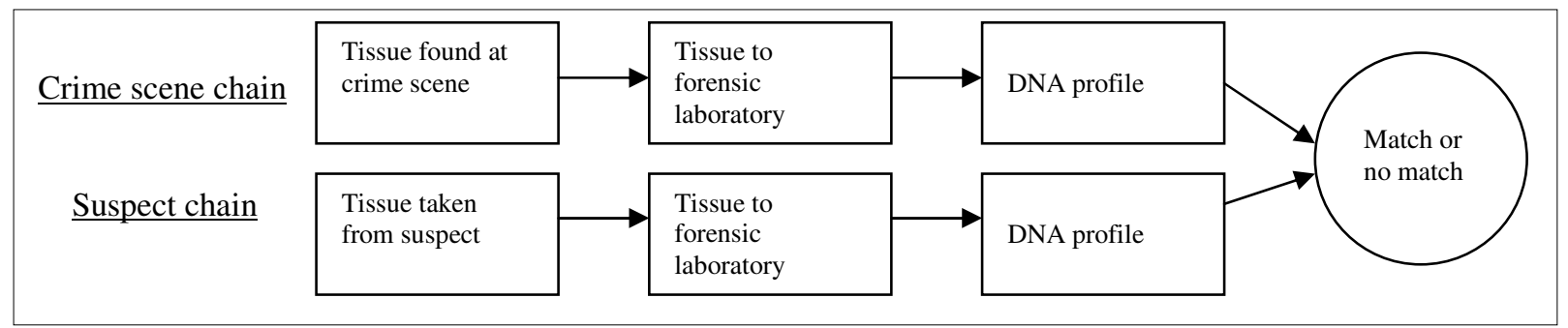

As I will argue in the present paper, making evidence convincing has repercussions for the legal protection of body parts as separated but undividable parts of an 
individual and his or her body. As a result, the legal concept of the right for inviolability of the body and its synonym bodily integrity will be problematised. ${ }^{10}$ Although the body of the victim is severely violated, the body of the suspect will be the focus of this paper, as that body is a starting point for examining the legal concept of the right to inviolability of the body.

The criminal investigation in the rape in disguise case led to an individual who became suspected of having committed both rapes. He was taken into custody on the basis of circumstantial evidence that related him to the rapes. The suspect was asked to deliver saliva and (pubic) hairs for comparison with samples secured during the physical examinations of both victims. The pubic hairs of the suspect matched those of the secured material. Blood types can be extracted from saliva, and the extracted blood types matched those of the tissue secured from the bodies of the victims. This is not to say that a sound link was established between the suspect and crimes, as the discriminatory value of these tests was considered very low. However, the results were deemed important as they did not exonerate the suspect as the possible perpetrator. On the other hand, there was also circumstantial evidence available warranting the suspect's claim to innocence. He did not match the physical description that both victims gave of the perpetrator, he was not identified by the victims during an Oslo-test, and they did not identify the voice of the suspect with that of the perpetrator. If the suspect's DNA fingerprint could be compared to that already produced from samples collected from the victims' bodies, then the juridical stalemate could be settled. Since the suspect pleaded innocence, the result could exonerate him as possible perpetrator. But when he was asked to deliver blood for DNA typing, the suspect refused to cooperate.

\section{Inviolability of the Body I: Boundaries of Bodies}

After the suspect's refusal to give blood for DNA typing, the investigating judge ruled that the suspect should be bodily searched in order to obtain blood. The suspect, together with his lawyer, appealed to the order in summary proceedings. They made an appeal to the right of inviolability of the body. Inviolability of the body is a fundamental right in the Dutch legislature; it is enshrined in article 11 of the Dutch Constitution: "Everyone shall have the right to inviolability of his person, without prejudice to restrictions laid down by or pursuant to Act of Parliament". ${ }^{11}$ In Dutch law, there was, at that time, no legal exception that made it possible to violate a suspect's body to take tissue against his will - hence the appeal judge's decision that blood could not be taken. Thereafter, the investigating judge ruled that the suspect should be bodily searched for a second time, now to obtain saliva. During both summary proceedings, legal concepts like insides and outsides of bodies, force, and tissue were articulated. Within the Dutch Constitution there is room for violating a body only "by or pursuant to Act of Parliament". In the penal code it states that tissue can be removed from the body. Here, "from the body" is articulated as from the outside, like on the skin or on clothes. However, "outside" is a discursive constructed category, as individuals who are suspected of smuggling drugs or weapons in "natural openings" can be searched in mouth, rectum, or vagina. So "natural openings" can be violated if a bodily search focuses on body-strange objects. To collect saliva from the mouth means that tissue is taken away from a natural opening. Yet, this was found not to be in accordance with the existing legislation and jurisprudence, and as a result the 
judge decided that mandatory taking of saliva from the mouth could not lead to legal evidence. ${ }^{12}$ This jurisprudence settled the legal position of blood and saliva as "private". ${ }^{13}$ They were inaccessible to the public authorities, and as a result DNA typing could not be applied to connect the suspect to both rapes. ${ }^{14}$ The suspect was kept in custody until the charges against him were brought to the judge. As there was no evidence that directly linked the suspect to the rapes, the judge concluded that it was neither convincingly nor legally proven that the suspect was the perpetrator. Therefore, the charges against the suspect were not found proven and he was released from custody. The rape in disguise case has never been solved.

\section{Inviolability of the Body II: Making the Private Public}

The process of jurisprudence through which tissues were shown to have a private status led to questions in the Dutch Parliament. Some members of the Parliament asked the Minister of Justice to change the law in such a way that in future cases tissue could be taken from a suspect with force. ${ }^{15}$ The minister reacted positively to the request, and installed a special forensic DNA commission, "Commissie Moons" (hereafter the "Moons Commission"), which was named after its chairman. The Moons Commission delivered a law proposal early $1991 .^{16}$ Three years later, in September 1994, the Forensic DNA typing law was enacted. Some elements of this Forensic DNA law will be discussed below, followed by an analysis of other laws relating to forensic DNA laws which came into force in 1994.

\section{Forensic DNA Typing Law - 1994}

The Netherlands was the first country in the world to introduce specific forensic DNA legislation. ${ }^{17}$ The law sought to ensure the reliability of forensic DNA practices, and it described in precise language and legal measures how tissue should be obtained from suspects and how the privacy of suspects and victims was to be protected. However, the most important achievement of this specific law was that it was no longer possible for suspects to make an appeal to the constitutional right to inviolability of the body in all situations. Since invading a body by breaching the skin was considered a serious violation of the legal concept of the "right to inviolability of the body", high thresholds were introduced. Tissue like blood in the body or saliva in the mouth could only be obtained by the public authorities for DNA typing if and when a person was suspected of having committed a crime with a penalty of a maximum of eight years or more, if there were serious suspicions against the suspect, when the suspect persisted in refusing to cooperate after being asked to do so several times, and if DNA evidence was essential for solving the case at hand. ${ }^{18}$ In practice, these criteria meant that the body of individuals, suspected of having committed serious and violent crimes like murder, manslaughter, and rape could be involuntarily violated in order to obtain tissue. The DNA fingerprint produced would be kept for a period of 30 years. The tissue collected was to be destroyed after a DNA fingerprint was produced, or as soon as the case at hand no longer required the availability of tissue. This last measure was to assure that tissue could not be used for other purposes, such as further genetic analysis. 


\section{Forensic DNA Typing in Criminal Proceedings Amendment - 2001}

Since the mid 1990s, the polymerase chain reaction (PCR) has been standard technology in (forensic) genetic laboratories. By means of PCR, specific DNA fragments (markers) can be reproduced outside a body. This meant that other tissues like saliva and hair roots could be used for forensic purposes. The availability of PCR was an important reason for an amendment to the 1994 law, the "Forensic DNA typing in criminal proceedings amendment" enacted in $2001 .{ }^{19}$ By means of the 2001 amendment the initial thresholds of the 1994 law were lowered, largely for two reasons. First, it became possible to produce DNA profiles from saliva; hence bodies were violated to a lesser extent (as was stated by the Dutch Minister of Justice). ${ }^{20}$ Second, the availability of PCR made it possible to look for new traces and clues (used cigarette tips, for example) at crime scenes. Therefore, PCR offered a way to use forensic DNA practices for more mundane crimes like burglary and car theft. Since the 2001 amendment, the number of cases in which tissue could be taken mandatorily increased significantly and consequently obtaining tissue from suspects became more mundane. To smooth the process of collection, some responsibilities were redistributed - the assignment of forensic experts to a case (redistributed from the investigating judge to the public prosecutor), for example, and the collection of saliva from consenting suspects (redistributed from medical doctors to trained police officers). Through the 2001 amendment, the right to inviolability of the body was articulated as the collection of tissue from the body. ${ }^{21}$ As a consequence, after the event of "touching" the body, collected tissue moved on to the legal realm of personal sphere and privacy elucidated by article 10 of the Dutch constitution: "Everyone shall have the right to respect for his privacy, without prejudice to restrictions laid down by or pursuant to Act of Parliament". ${ }^{22}$ Hence, tissue and the DNA it contains have, since the 2001 amendment, been understood as personal data that jeopardises the personal sphere and privacy; the bodily integrity of biological material outside of bodies is legally no longer taken into account. Both the DNA profiles and the forensically collected biological material are now to be kept for a 20- or 30-year period. $^{23}$

\section{Law on External Visible Characteristics - 2003}

After the 2001 amendment, legal measures to give room to forensic DNA practices followed quickly as the result of new forensic-genetic techniques and the political wish to use these techniques. One such technique is the use of markers on the male $Y$ chromosome to make predictions about geographical descent of the donor of the tissue found at a crime scene. As the 1994 law and the 2001 amendment explicitly prohibited the usage of coding DNA, a new law had to be made that permitted forensic-genetic research on markers that code for external visible characteristics. In 2003 the "Law on external visible characteristics" came into force. ${ }^{24}$ It referred to forensic-genetic research on biological traces found at crime scenes. ${ }^{25}$ By means of the law it has become a legal option to search for external visible characteristics (currently gender, and prediction about geographical descent by using DNA fragments situated on the male Y chromosome and parts of mitochondrial DNA (mtDNA)). ${ }^{26}$ These forensic-genetic technologies add a new function to forensic DNA practices: the data produced can enable investigations to focus on particular 
(ethnic) groups. Similarly, forensic-genetic analyses can exonerate possible suspected groups. $^{27}$

\section{The Dutch DNA Testing (Convicted Persons) Act - 2005}

Since 2005 , it has been possible mandatorily to take the tissue of already convicted criminals (before it was only allowed to do so from suspects). ${ }^{28}$ According to, among others, politicians, the storage of DNA and DNA profiles for a 20- or 30-year period will prevent future crimes. Moreover, the stored DNA profiles can be used to search automatically for matches between crime scenes, and for matches between known persons and as yet unsolved crimes. The tissue is to be kept for future use, or to be profiled again if necessary. The DNA profiles produced are stored in the Dutch DNA database, which contains currently around 25,000 profiles of known individuals. ${ }^{29}$

As this brief introduction to Dutch forensic-genetic legislation and techniques shows, the applicability of forensic DNA practices to criminal investigations has increased through new legislation and new techniques, and there is political agreement that these practices contribute to a safe society. The application of forensic DNA practices has gradually shifted from that of evidence and identification to criminal investigation and prevention of future crimes. ${ }^{30}$ In the process of giving room to new forensic DNA practices, the relationship between civilians and the authorities has changed, i.e. giving the state jurisdiction over intimate samples by redefining the right to inviolability of the body. But other legal principles that serve to protect individuals against use, abuse or misuse of violence by the state have been renegotiated too, like privacy, prohibition of discrimination (the 2003 law), presumption of innocence and motivation for criminal investigation by police (DNA databases, population wide DNA screenings), and the division between penal law for adults and adolescents (The Dutch DNA testing (convicted persons) act ${ }^{31}$ ). Discussion about the costs for legal principles of giving more room to forensic DNA practices have, with some exceptions, ${ }^{32}$ emerged only recently. ${ }^{33}$

\section{Inviolability of the body \& bodily integrity}

For the sake of the argument presented in the paper, the "suspect chain" (fig.1) and "convincing evidence" will be examined more thoroughly here. As already stated, a judge can only become convinced that the presented evidence links the suspect to the crime through a demonstrably unbroken chain of evidence. In the practice of making evidence convincing, obtained tissue must always be accompanied by information about the individual it belongs to; simultaneously this package of tissue and information about identity (ID) has to travel back and forth from a body to a forensic laboratory without losing form. ${ }^{34}$ Hence a tissue/ID-package is constructed. As long as the tissue/ID-package functions, the tissue of a suspect can be made into convincing DNA evidence. However, as it has now been stipulated that tissue can be obtained from the "insides" of bodies if the legal criteria are met, it will be argued that a functioning tissue/ID-package jeopardises the donor's right to inviolability of the body/bodily integrity and privacy.

As long as the tissue and information about the individual are kept together, the tissue can be understood as belonging to the body of that individual. Hence, by means of the 
tissue/ID-package, specific parts of bodies of individuals whose tissue will be DNA typed travel through time and space without losing form. Since those travelling body parts of individuals still are related to the donor by means of the tissue/ID-package, the right to inviolability of the body/bodily integrity (article 11 of the Dutch constitution) and privacy (article 10 of the Dutch constitution) of the donor are also at stake: information about the identity of the donor enacts the bodily integrity of travelling tissue; the flip side of this is that tissue contains genetic information which enacts the privacy of the individual. ${ }^{35}$ Once tissue has been obtained and translated into the tissue/ID-package it no longer belongs to the legal realm of article 11 of the constitution that governs bodily integrity. Instead, legal protection of the tissue/IDpackage moves to the privacy and personal information provisions outlined in article 10 of the constitution, which can be problematic, as personal information should be understood as a produced DNA profile, a medical record, or a social security number. By applying genetic techniques on tissue and the DNA it contains, information can be revealed about the donor. Such information concerns body and mind, the donor and his or her family, an individual and population. The argument presented in this paper is that legislation designed to protect personal life is not sufficient to protect such problematic normative and ethical issues, especially if one takes in account that tissue/ID-packages are stored for a period of 20 or 30 years. Instead, protecting the tissue/ID-package as biological material and indivisible (if separate) part of an individual would be better organised by articulating and diverging bodily integrity as a legal concept to protect tissue outside bodies.

\section{Conclusion}

In the Netherlands, protection of tissue within bodies by means of the right for inviolability of the body was problematised when the Office of Public Prosecution wanted to apply the novel DNA fingerprint technique, as discussed with respect to the rape in disguise case. Therefore, the rape in disguise case can be considered a milestone for Dutch forensic DNA practices and their legal arrangements. By means of the Forensic DNA law it became a legal possibility to violate the insides of bodies to collect tissue for DNA typing. Because the use of force to obtain tissue was considered a serious violation of bodies, high thresholds were introduced initially. Later, by means of the 2001 amendment and the 2005 law, the categories of individuals whose bodies could be violated were expanded. ${ }^{36}$ By means of the law enacted in 2003 on external visible characteristics, and through the intensified use of the Dutch DNA database, forensic DNA practices received new applications. At first, DNA typing was used as evidence and for identifying purposes. Later, DNA typing was also considered as a tool for criminal investigation and the prevention of crimes. This paper aims to articulate the legal-normative concerns that accompany the applications of forensic DNA analysis.

This paper places the suspect in the foreground, as the suspect's body is an entry point to aid description of the re-articulation or re-negotiation of, in this case, the right to inviolability of the body. The right to inviolability of the body is a principle that protects the population at large from the authorities and their monopoly for using violence, for example torture. As more room has been given to forensic DNA practices, the possibilities for making an appeal to such legal principles have been reduced. As described above, the 1994 law stipulated that the tissue/ID-package 
should be destroyed after a DNA fingerprint had been produced as a precautionary measure against misuse and abuse of tissue. By means of the 2001 amendment this warrant has been terminated. The tissue/ID-package is now to be stored for a 20 or 30 year period.

One would expect that the storage of the tissue/ID-package for two or three decades has been firmly legally arranged. This paper shows that the legal arrangements for dealing with the tissue/ID-package itself are at fault. In the process of making legal evidence convincing, a chain of evidence is compiled. The tissue/ID-package is part of that chain of evidence. The function of the tissue/ID-package is to keep tissue and information about the donor's identity together, and hence the obtained tissue still is an indivisible part of the donor's body with claims to bodily integrity. As a result, one would expect that the tissue/ID-package is subject to a legal framework that protects bodily integrity. This is not the case in current Dutch forensic DNA practices, as the legal concept of the right to inviolability of the body has been understood as the right not to be touched by the authorities except such as is by or pursuant to Act of Parliament. Currently the tissue/ID-package is protected by the legal concept of privacy. Privacy has not been articulated as to protect body parts of identifiable individuals but to protect personal life, therefore the legal framework of privacy no longer suffices the protection of the tissue/ID-package. ${ }^{37}$ A solution to this problem is to articulate bodily integrity as a legal concept that governs the protection of body parts, e.g. the tissue/ID-package, outside of bodies.

\footnotetext{
${ }^{1}$ A. Jeffreys et al. Hypervariable 'minisatelite' regions in human DNA. Nature 1985; 314: 67-73.

${ }^{2}$ This paper uses insights of a case study that has been financed by the Dutch organisation for scientific research (NWO). I would like to thank the participants of $10^{\text {th }}$ colloquium of the Post Graduate Forum on Genomics and Society (PFGS) for their feedback on an early draft of this paper that was presented during the annual colloquium. I am grateful to Merel Prinsen, Amade M'charek, John Grin, and two anonymous reviewers for their valuable comments. I want to thank Jessica Wright especially for commenting on the paper and for helping me to improve the English.

${ }^{3}$ For the analysis of the rape in disguise case, I used the data collected in the criminal file of the case Pro justitia (1989), no. 7297/1989. It contains privacy-related information. Hence, access to such a file is limited. To get access, the Board of Procurators General, the highest juridical authority in the Netherlands, had to give permission. The research team (John Grin, Amade M'charek and I) signed a special code for scientific research "Verklaring inzake de toestemming van het College van procureursgeneraal namens de Minister van Justitie, met betrekking tot inzage [....], ten behoeve van het onderzoek naar het gebruik van forensisch DNA", which covers the rights and duties of both researcher and who and what is being researched, as well as privacy issues of suspected people, victims, and witnesses.

${ }^{4}$ To prevent jeopardising privacy of victims, suspects, and the family of people involved, I describe the modus operandi of the rape only in vague terms.

${ }^{5}$ In the present, likelihood ratios of more than one in a billion can be calculated.

${ }^{6}$ The analysis presented here is inspired by the work of Dutch empirical philosopher Annemarie Mol. (A. Mol. 2002. The Body Multiple: Ontology in Medical Practice. Durham. Duke University Press.) Mol's praxiography centres the hands of practioners, the instruments used, knowledge built into technologies, microscopes, blood, records, publications, and fluids to study practices in which knowledge is embedded. The plot of her philosophical tale is: "that ontology is not given in the order of things, but that, instead, ontologies are brought into being, sustained, or allowed to wither away in common, day-to-day, sociomaterial practices" (p. 6).

${ }^{7}$ The NFI, and the Forensic laboratory for DNA research (FLDO) in Leiden.
} 
${ }^{8}$ Transparency of the chain of evidence enables me, as a social scientist, to reconstruct the process of case-making. So (getting access to) a criminal investigation file is my method for writing about forensic-genetic practices in the Netherlands.

${ }^{9}$ This also means that evidence and the production of certainty can be questioned. See: M. Lynch. The Discursive Production of Uncertainty: The OJ Simpson 'Dream Team' and the Sociology of Knowledge Machine. In Social Studies of Science, Vol. 28, No. 5/6, Special Issue on Contested Identities: Science, Law and Forensic Practice, Oct. - Dec., 1998: 829-868; L. Derksen. Towards a Sociology of Measurement: The Meaning of Measurement Error in the Case of DNA Profiling. In Social Studies of Science 2000; 30(6): 803-845.

${ }^{10}$ The Dutch constitution articulates the concept as inviolability of the body ("onaantastbaarheid van het lichaam"), hence I use it, too.

${ }^{11}$ The Constitution of the Kingdom of the Netherlands. 2002. Published by the Ministry of the Interior and Kingdom Relations, Constitutional Affairs and Legislation Department, in collaboration with the Translation Department of the Ministry of Foreign Affairs. In the English translation of article 11, it was decided to translate "lichaam" (body) in "person". In the Dutch context, this specific law is understood as related to "body" and not to "person". The Dutch text is: "Ieder heeft, behoudens bij of krachtens de wet te stellen beperkingen, recht op onaantastbaarheid van zijn lichaam" (artikel 11 Grondwet).

${ }^{12}$ In the UK, removing saliva from the mouth is no longer a violation of civil Constitutional rights. For a case study about the UK DNA databank and the issue of collecting tissue see: P. Johnson et al. Genetics and Forensics: Making the National DNA Database. Science Studies 2003; 16(2): 22-37.

${ }^{13}$ David Delany has published fascinating account of the constructive power of the law and its effects on the construction of nature: D. Delaney. Making nature/marking humans: Law as a site of (cultural) production. In Annals of the association of American Geographers 2001; 91(3): 487-503.

${ }^{14}$ The Office of Public Prosecution appealed to the judge's decision in the Constitutional Court. The judge's decision was confirmed in the so-called saliva-decision. NJ 1990/751. 1990. "Wangslijm arrest." Hoge Raad der Nederlanden.

15 Tweede Kamer. 1989 - 1990. Aanhangsel 86. p. 173.

${ }^{16}$ Commissie Moons. 1991. Het DNA-onderzoek in strafzaken: een rapport van de Commissie herijking Wetboek van Strafvordering.

${ }^{17}$ A. M'charek. 2005. Populatie in het Forensisch DNA-Onderzoek: Van Probleem naar Mogelijkheid? In Ethiek van DNA tot 9/11. Johan Braeckman et al, eds. Amsterdam University Press.

${ }^{18}$ Staatsblad. 1994. 522. Besluit DNA-onderzoeken.

${ }^{19}$ Staatsblad. 2001. 400. Besluit DNA-Onderzoek in Strafzaken.

${ }^{20}$ Tweede Kamer der Staten Generaal. Vergaderjaar 1998-1999. Wijziging van de Regeling van het DNA-onderzoek in Strafzaken: Memorie van Toelichting. 26271. nr. 3. p. 1.

${ }^{21}$ M'charek, op. cit. note 17, p. 109; Ludvig Beckman (2005: p. 98) made the same argument in a recent paper, where he describes that bodily integrity is at risk only when biological material is collected. L. Beckman. Democracy and Genetic Privacy: The value of Bodily Integrity. In Medicine, Health Care and Philosophy 2005; 8: 97-103.

${ }^{22}$ The Constitution of the Kingdom of the Netherlands, op. cite 11. "Ieder heeft, behoudens bij of krachtens de wet te stellen beperkingen, recht op eerbiediging van zijn persoonlijke levenssfeer" (Artikel 10 Grondwet).

${ }^{23}$ DNA and DNA profile collected in non-violent crimes are to be stored for a 20 year period, and for 30 years in violent crimes. Violent and serious crimes are defined in terms penalty with a maximum of 6 years imprisonment or more.

${ }^{24}$ Staatsblad. 2003. DNA-onderzoek in strafzaken in verband met het vaststellen van uiterlijk waarneembare persoonskenmerken uit celmateriaal.

${ }^{25}$ See M'charek, op. cit. note 17; B.J. Koops and M. Prinsen. 2005. Gezocht: blonde man uit Friesland. Verwonderpunten bij de wet DNA-onderzoek uiterlijk waarneembare persoonskenmerken. In Delikt \& Delinkwent 35(6) p. 610-626.

${ }^{26}$ It is expected that new applications will be developed in the near future. Therefore, the government has made a deliberate choice to allow these techniques by issuing a governmental decree.

${ }^{27}$ This is what happened when forensic analysis was performed in a notorious Dutch case of murder in the province of Friesland. A 16 year old girl, Marianne Vaatstra, was raped and killed in May 1999. Crimimal investigation led to various suspects, but they were all exonerated after delivering tissue for DNA typing. The local Fries population soon started to suspect inhabitants of the nearby centre for asylum seekers, which led to a period of suspicion, discrimination, and resistance towards the asylum 
seekers. In one of the two forensic-genetic Dutch laboratories, a Y-chromosome DNA test was performed on tissue that probably belonged to the (unknown) perpetrator. The results of the test matched Y-chromosomes of North-Western Europeans rather than the suspected Iraqis, Afghanistanis and Kurds. For an 'inside' account around the forensic-genetic events related to the murder on Marianne Vaatstra, see P. de Knijff. 2006. Meehuilen met de wolven? Inaugural lecture. Leiden. ${ }^{28}$ Staatsblad. 2004. 465. Wet DNA-onderzoek bij veroordeelden.

${ }^{29}$ For an up-to-date overview of the amount of DNA profiles in the Dutch DNA database, see http://www.dnasporen.nl.

${ }^{30}$ In this paper, I will not go into the consequences of these shifts. The applications of forensic-genetic practices will be central to my forthcoming doctoral dissertation. See also M'charek op. cit. note 17. For an interesting article about DNA profiling and the different "identities" of forensic-genetic technologies, see S. Jasanoff. 2004. DNA's Identity Crisis. In DNA and the Criminal Justice System: the Technology of Justice. D. Lazer, ed. The MIT Press.

${ }^{31}$ M. Levitt and F. Tomasini. Bar-coded Children: An Exploration of Issues around the Inclusion of Children on the England and Wales National DNA Database. Genomics, Society and Policy 2006; 2(1): 41-56.

${ }^{32}$ T. de Roos. Slachtoffer, verdachte en de DNA-proef. Nemesis 1990; 3: 123-9.

${ }^{33}$ S. L. J. Janssen. De Wet DNA-onderzoek bij veroordeelden. Or How I learned to stop worrying and love DNA. Nederlandsch juristenblad 2004; 79: 1292-1298; S. Zuidwijk. DNA-onderzoek in strafzaken, een almaar voort-razende trein. Trema 2003; 26: 267-275.

${ }^{34}$ This is what French anthropologist of science Bruno Latour calls an immutable mobile. An immutable mobile is a concept that enables one to think about traveling objects from one domain to another without losing form and content. B. Latour. 1990. Drawing things together. In Representation in Scientific Practice. M. Lynch and S. Woolgar, eds. The MIT Press: 19-68; For another immutable mobile within a forensic-genetic context, see: A. M'charek. 2005. Technologies of Population: Making Differences and Similarities between Turkish and Dutch Males. In The Human Genome Diversity Project: An Ethnography of Scientific Practice. Cambridge University Press. pp. 21-55.

${ }^{35}$ The Dutch legal arrangement concerning inviolability of the body and privacy differs from legal arrangements in other countries. Although there seems to be no consensus about the exact meaning of privacy in the context of genetic practices, some scholars do make a distinction between spatial and informational privacy. Spatial privacy refers to an individual's physical space and non-accessibility of that space, e.g. touching or entering bodies. Informational privacy is to be understood as personal information about a person, e.g. data produced from genetic material. See for instance: G. Laurie. 2002. Genetic Privacy: A Challenge to Medico-Legal Norms. Cambridge University Press; see also Beckman op. cit. note 21

${ }^{36}$ One could ask whether this movement, in which fundamental rights of individuals in a State of Law are redefined to enable the state to survey or to identify, is desirable. For an elaborate discussion, see: A. Etzioni. 2004. DNA Tests and Databases in Criminal Justice: Individual Rights and the Common Good. In DNA and the Criminal Justice System: the Technology of Justice. D. Lazer, ed. The MIT Press.

${ }^{37}$ A similar point is made by Irma van der Ploeg: "So, if the underlying ontology [of a body] is gradually changing through processes of information, digitization, and the various new forms of constructing, performing and manipulating the body these transformations allow, and if because of that the presumed demarcation of where 'the body itself' stops and begins being 'information' will subtly shift, the moral and legal vocabularies available will no longer suffice.” I. van der Ploeg. 2003.

Biometrics and the Body as Information: Normative Issues of the Socio-Technical Coding of the Body. In Surveillance as Social Sorting: Privacy, Risk and Digital Discrimination. D. Lyon, ed. Routledge, p. 67. 